\title{
Share repurchases, coronaeconomy and stakeholders' interests
}

\author{
Irina Tkachenko ${ }^{1, *}$, and Bela Bataeva ${ }^{2}$ \\ ${ }^{1}$ Ural State University of Economics, st. March 8, 62/45, 620144 Yekaterinburg, Russia \\ ${ }^{2}$ Financial University, Moscow, Russia
}

\begin{abstract}
The purpose of the paper is to consider the mechanism of share repurchases in the context of the coronaeconomy and the COVID-19 pandemic. The English- and Russian-language publications discussing share repurchases from the perspective of the stakeholder approach in corporate governance are reviewed. The practice of the Russian firms implementing share repurchase programs is analyzed, with the focus on the companies included in the Sustainable Development Ranking-100. It is concluded that share repurchases should be studied with regard to the impact they have on the interests of a wide range of company's financial and non-financial stakeholders, and to the mutual influence of buybacks and parameters of sustainable economic development.
\end{abstract}

\section{Introduction}

The amounts paid to shareholders as share repurchases, rather than dividend payments have increased dramatically over the last few decades. Until recently, corporate governance theory believed that corporations exist to earn profits for shareholders. With the spread of corporate social responsibility (CSR) and corporate sustainability concepts, the focus has shifted from shareholders' benefits to the benefits of different stakeholders and to long-term sustainability. Questions have been raised about whether companies are using cash resources wisely and whether future growth and job creation are still a priority when deciding whether to use excess cash.

Repurchasing shares, or share buybacks, is a procedure when the issuer buys back its own shares, which may lead to a decrease in the number of freely traded securities and an increase in share prices. Share repurchases were allowed in the United States in1960, but became popular when Rule 10b-18 was passed by Congress in 1982 and amended in late 2003. As a result, the S\&P 500 dividend payout ratio slid from 55\% in 1969 to around $25 \%$ in 2013 [1]. In the USA total share buybacks topped the one trillion mark for the first time in 2015 and had exceeded dividend payouts since 2005. In 2014 the value of repurchasing shares in the United States exceeded the value of new shares issued by five times [2].

In the United Kingdom, share buybacks were legalised in the 1980s. In the continental Europe, share repurchases became popular in the mid-1990s; in Asia - in the late 1990s.

\footnotetext{
* Corresponding author: Tkachenko@usue.ru
} 
How popular are share buybacks in Russia? Share repurchases started to be used as the payment method by Russian firms to maintain shareholder value when the United States and EU countries introduced the sanctions related to the annexation of Crimea to Russia in 2014. In 2018 - 2019, buybacks were already considered the main trend. According to the National Rating Agency (NRA), transactions worth 39 billion rubles were conducted in the open market in Russian in the first half of 2018. The number of buybacks was expected to decrease in 2020, but the spread of the COVID-19 virus has made its own adjustments. In 2020, numerous Russian firms have been repurchasing shares, thereby affecting stock prices. Yet it takes time to see the long-term effect of this behaviour. The risks associated with buybacks may increase and the expected returns may not be gained.

The objective of the paper is to study the conceptual approaches to share repurchase behaviour in international and Russian literature and to see how this payout method meets corporate stakeholders' interests. The article also aims to identify benefits and shortcomings of share repurchases and to provide empirical evidence on the extent of using buybacks in Russian companies particularly under the threat of coronavirus. The authors are also making an attempt to analyze how the share purchase behaviour affects long-term sustainability.

\section{Review of conceptual approaches}

The majority of publications on share repurchases, both overseas and in Russia, dates back to the global economic and financial crisis in 2008-2009. The study of the Google Scholar bibliographic database dating from the early 1990s has shown that only one third of English-language publications on share repurchases considers corporate governance issues, and only $1 / 5$ of the publications mention company stakeholders. The Russian-language publications on buybacks are few in number. Drawing on the purpose of our research, in the review we have focused on the publications that study various aspects of corporate governance, including the impact of buybacks on stakeholders' interests rather than those researching a conventional approach to repurchasing shares as an aspect of corporate finance.

We start our review with the work of Evgeniou T. et al. (2018) [3] where the authors tested the arbitrage and the market timing hypotheses about the presence of abnormal longterm excess returns following buyback announcements. They are calculated on the basis of the five factors Fama and French (2015) [4] and the four factors of the Stambaugh and Yuan (2017) model [5]. The authors draw attention to the fact that buybacks may target a specific group of shareholders, top management, rather than collective shareholders and stakeholders.

The broader context of issues related to the economic impact of stock buybacks on a wide group of stakeholders was analyzed in [6]. The author examines the impact of the Tax Cuts and Jobs Act (TCJA), passed in the USA in December 2017, on investment. The TCJA brought many changes to the US federal tax code, including lowering the corporate tax rate from $35 \%$ to $21 \%$. The article argues that tax reduction has resulted in higher cash flow for many firms and some companies have made their choice in favour of returning portions of that cash to their shareholders through share repurchases.

The analysis of relationships between the short-term financial gains for managers arising from share repurchases and the long-term effects on the company's competitiveness [7] proves that an increase in the stock-based manager remuneration leads to shifting investments towards stock buybacks. This, while pushing the share price up in the short term, negatively affects the dynamic of firm's profits in the long run.

Some researchers [8] believe that buybacks are used to manipulate stock prices in the market, which may lead to a disproportional distribution of national income. Most 
buybacks occur when stock prices are high, in order to offset dilution of earnings per share (EPS) that results when the company offers stock options to its employees. Buybacks make no contribution to innovative growth of the economy, but are at the core of what Lazonick calls the "downsize-and- distribute" economy [8, p. 7]. Government policy should regulate the stock market for the sake of the middle class and the majority of the population, i.e. in the interests of broad stakeholders. In his further paper [9], Lazonick et al. state that massive repurchases are used by senior corporate executives to manipulate their companies' stock prices to their own benefit, since most of their remuneration comes from stock options and stock rewards. Buybacks enrich these opportunistic share sellers - investment bankers and hedge-fund managers as well as senior corporate executives - at the expense of employees as well as continuing shareholders. As a mode of distributing corporate funds to shareholders, buybacks surpassed dividend payouts in 1997. Since then, buybacks, which are much more volatile than dividends, have dominated distributions to shareholders when the stock market was booming. The authors argue that stock buybacks undermine the quest for fair and stable economic growth and should be banned.

Commenting on the connection between stock buybacks and dividends, Gruber \& Kamin [10] tested the hypothesis that dividend and buybacks may be a consequence of pessimism about future demand and economic growth. Corporations defer capital spending, and simply return money to their shareholders to pursue more attractive investment opportunities.

Under the conditions of social and economic turmoil and a rapidly changing business landscape caused by the COVID-19 pandemic, the importance of the corporate governance paradigm based on the stakeholder approach has become relevant as never before. In 2020, many studies are addressing a changing attitude to stakeholders along with a continuous analysis of share repurchases popularity both in foreign countries and Russia. The search query for the keywords buybacks, stakeholders, COVID-19 in Google Scholar has shown 159 English-language articles. By the beginning of November 2020, 81 articles have been published that are analyzing the impact of share buybacks on company's stakeholders. Definitely, the relationship between buybacks and the stakeholder model needs to be studied in the long run, but the problem statement itself and the application of the model of sustainable development and conscious capitalism are attracting recent research interest $[11,12]$.

Answering the questions how industrial companies with global manufacturing and supply chain can survive the impact of the COVID crisis, Sheth [13] argues that company management should support and protect all of its stakeholders and broaden the purpose of business. The leadership of the company should postpone the implementation of their share repurchases plans. The investor is just one of the stakeholders and not the only one, This will require senior executives to shift from a win-loss mindset to a win-win mindset that could be beneficial for everyone. .

Providing state support to companies during the pandemic, Western governments require that in receipt of this support firms would maintain all of their current employees, regardless of their contract type and the pay of government bonds, dividends, share repurchases and executive remuneration should be suspended until termination. In addition, the gains from future business recovery and equity gains should be distributed fairly among stakeholders. The latter will ensure changes in corporate governance and behaviour that are consistent with overall long-term environmental and ethical goals [14].

Discussing the incentives and consequences of buybacks, experts mainly highlight positive trends while neglecting cons of this process for a wide range of company's stakeholders, and not just for a narrow group of shareholders and top management: if the money indulgence in this elite group cannot be curbed, examples of managerial opportunism on a daily basis will be multiple [15]. 
The idea that governments have to accept a more active role in the economy is promoted in the report of the Labour Party [16]. Over the past decade there have been widespread calls for a more responsible capitalism. The mistakes of the 2008 financial crisis should not be repeated, when government support has facilitated even higher aftercrisis gains. The corporate governance framework needs to be re-configured to support responsible business focused on long-term, sustainable success, shared by all their stakeholders.

The overview of publications allows us to conclude that most of the literature rarely aims at analyzing the impact of share repurchases on company's financial stakeholders. Still rare are works where the impact of stock buybacks is looked upon from the point of view of non-key, non-financial stakeholders and what could be done to reduce the ability of corporate insiders to use stock buybacks for personal gain [17].

The existing literature in the Russian language is even scarcer. Neither Google Scholar nor the E-library database has found any study, dated this year, of the relationship between such concepts as share repurchases, stakeholders' interests, sustainable development, and COVID-19. There are several analytical articles by stock market and BCS Express experts that identify the latest trends in buybacks practice in the Russian business, but deep analysis of benefits and shortcomings of share repurchases for all groups of stakeholders, especially in the context of the pandemic is almost non-existent. Consequently, the transition from verbal descriptions of the impact of the buybacks on corporate governance and all stakeholders to a real analytical endeavour and modelling of stakeholders' benefits seems to be an urgent task $[18,19]$.

The same trend - the focus on financial outcomes of stock buybacks - dominates the publications of Russian researchers. They argue that buybacks can mislead investors and incentivize senior executives only [20]. At the same time share repurchases can be used to increase company's economic value added [21] and can motivate top management to satisfy shareholders' interests [22].

\section{Methodology}

The conceptual and methodological basis of our research is to search and analyze studies performed in the field of share repurchases and their impact on the interests of all stakeholders. The following methods have been used: content analysis, comparative analysis, and synthesis. When analyzing analytical and expert data, an assumption was made that, on the one hand, market turbulence caused by the pandemic and the threat of a global recession make companies repurchase shares in order to maintain their price. On the other hand, buybacks are an ambiguous tool. This mechanism not only has a positive impact on equity, but also poses risks for certain groups of stakeholders, significantly increasing the wealth and earnings of some, and making others poorer. The authors studied the data of expert and rating agencies, raising the question not only about the welfare of stakeholders, but also about the presence (or absence) of the impact of buybacks on the company sustainable development.

\section{Results and Discussion}

\section{Market decline and stock buybacks}

The 2020 crisis has resulted in market decline, which has encouraged Russian companies to actively use buybacks to maintain the value of its shares. In March 2020, the Russian index fell by $25 \%$. This prompted several Russian companies to announce the start of new buyback programs or the extension of the currently run programs [23]. 
On March 23-27, 2020, Rosneft repurchased 4936260 shares and 1889977 global depository receipts (GDR) on the open market, which totalled $\$ 25.7$ million (about 2 billion rubles) and constituted $0.06 \%$ of the authorized capital. Rosneft buyback was accompanied by a quotation fall by an average 402 million rubles per day. The proportion of share buybacks to the trading volume accounted for 5.1\% [24]. On March 18, 2020, Detsky Mir purchased 1212210 shares worth approximately 90 million rubles $(0.16 \%$ of the equity capital). TCS Group acquired 650 thousand GDR from March 12 to 15, 2020.

Other companies, such as Lukoil, Sistema, Yandex, Transneft, Novatek, Safmar, that had approved share repurchase programs in 2019, took advantage of the situation and bought back larger blocks of shares than it had been planned. For example, Sistema that had approved a 3 billion rubles buyback program in September 2019, extended share repurchases till December 31, 2020. As of February 28, 2020, a subsidiary of Sistema repurchased 120.6 million shares worth 1.6 billion rubles. This is equivalent to $40.2 \%$ of the declared maximum number of shares and $54.8 \%$ of the amount allocated for the program [25]. Novatek had announced a buyback program in 2018. In 2020 the company increased the size of its buyback program; from the beginning of the year, Novatek has repurchased 2.5 times more shares than in 2019 and 1.6 times more than at the end of 2018 . Lukoil approved a \$ 3 billion share repurchase program in October 2019 and it will last till 2022.

Share repurchases activity of Russian companies from 2018 to 2020 is presented in Table 1. It also shows companies' positions in the sustainable development ranking

Table 1. Ranking of Russian firms with competed and non-completed repurchase programs

\begin{tabular}{|c|c|c|c|c|}
\hline Company & Program timescale and rate of delivery & $\begin{array}{c}\text { Size of } \\
\text { repurchase }\end{array}$ & $\begin{array}{l}\text { Ratio of } \\
\text { buyback to } \\
\text { total equity } \\
\text { capital (\%) }\end{array}$ & $\begin{array}{l}\text { Sustainable } \\
\text { Development } \\
\text { Ranking-100 }\end{array}$ \\
\hline \multicolumn{5}{|c|}{ Panel A: Non-completed repurchase programs } \\
\hline Rosneft & $\begin{array}{c}\text { Rate of delivery: } 18.48 \%(\$ 369.5 \mathrm{ml}) \\
\text { Start: August } 06,2018 \\
\text { Finish: December } 31,2020\end{array}$ & $\$ 2 \mathrm{ml}$ & 3.2 & 2 \\
\hline Lukoil & $\begin{array}{c}\text { Rate of delivery: } 0 \% \\
\text { Start: October 01, 2019 } \\
\text { Finish: December 30, } 2022 \\
\end{array}$ & $\$ 3 \mathrm{ml}$ & 5.1 & 5 \\
\hline Novatek & $\begin{array}{c}\text { Rate of delivery: } 61.22 \%(\$ 367.3 \mathrm{ml}) \\
\text { Start: June } 07,2012 \\
\text { Finish: June } 07,2021 \\
\end{array}$ & $\$ 600 \mathrm{ml}$ & - & 8 \\
\hline MTS & $\begin{array}{c}\text { Rate of delivery: } 86.44 \% \text { (RUR12.97 ml) } \\
\text { Start: March 31, } 2020 \\
\text { Finish: December } 31,2020\end{array}$ & RUR $15 \mathrm{ml}$ & - & 11 \\
\hline Transneft & $\begin{array}{c}\text { Start: June } 2019 \\
\text { Finish: } 2022 \\
\end{array}$ & RUR $20 \mathrm{ml}$ & - & 40 \\
\hline TMK Group & $\begin{array}{c}\text { Start: April } 2020 \\
\text { Finish: not known } \\
\end{array}$ & & - & 55 \\
\hline Sistema & $\begin{array}{c}\text { Rate of delivery: } 54.84 \% \text { (RUR } 1.65 \mathrm{ml}) \\
\text { Start: September } 17,2019 \\
\text { Finish: December } 31,2020\end{array}$ & RUR $3 \mathrm{ml}$ & 3.1 & 67 \\
\hline Globaltrans & $\begin{array}{c}\text { Rate of delivery: } 0.87 \%(76.88 \text { th shares) } \\
\text { Start: May } 12,2020 \\
\text { Finish: May12, } 2021\end{array}$ & $8.84 \mathrm{ml}$ shares & 5 & - \\
\hline LSR Group & $\begin{array}{c}\text { Rate of delivery: } 0 \% \\
\text { Start: March } 26,2020 \\
\text { Finish: not known }\end{array}$ & RUR $5 \mathrm{ml}$ & - & - \\
\hline $\begin{array}{c}\text { Safmar } \\
\text { Financial } \\
\text { Investments }\end{array}$ & $\begin{array}{l}\text { Start: November } 2018 . \\
\text { Finish: November } 2021\end{array}$ & RUR 6 ml & - & - \\
\hline
\end{tabular}


Table 1. Continued

\begin{tabular}{|c|c|c|c|c|}
\hline Detsky Mir & $\begin{array}{c}\text { Rate of delivery: } 0 \% \\
\text { Start: February } 08,2020 \\
\text { Finish Fenruary } 07,2023\end{array}$ & - & - & - \\
\hline $\begin{array}{l}\text { RusAqua } \\
\text { (Russian } \\
\text { Aquaculture } \\
\text { ) }\end{array}$ & $\begin{array}{c}\text { Rate of delivery: 49\% (RUR } 294 \mathrm{ml} \text { ) } \\
\text { Start: December 11, } 2019 \\
\text { Finish: June 30, } 2021\end{array}$ & RUR $600 \mathrm{ml}$ & - & - \\
\hline Yandex & $\begin{array}{c}\text { Rate of delivery: } 52.1 \%(\$ 156.3 \mathrm{млн);} \\
\text { Start: November } 18,2019 \\
\text { Finish: not known } \\
\end{array}$ & $\$ 300 \mathrm{ml}$ & - & - \\
\hline $\begin{array}{l}\text { Etalon } \\
\text { Group }\end{array}$ & $\begin{array}{c}\text { Start: January 27, } 2020 \\
\text { Finish: December 30, } 2024 \\
\end{array}$ & $\$ 400 \mathrm{ml}$ & 10 & - \\
\hline Globaltruck & $\begin{array}{c}\text { Rate of delivery: } 45.41 \%(1.33 \mathrm{ml} \text { shares }) \\
\text { Start; November } 11,2019 \\
\text { Finish: May } 31,2021 \\
\end{array}$ & $2.92 \mathrm{ml}$ shares & 5 & - \\
\hline Obuv Rossii & $\begin{array}{c}\text { Rate of delivery: } 1.5 \% \text { (RUR } 13.51 \mathrm{ml}) \\
\text { Start: October 26, } 2018 \\
\text { Finish: December 31, } 2020 \\
\end{array}$ & RUR $900 \mathrm{ml}$ & - & - \\
\hline \multicolumn{5}{|c|}{ Panel B: Completed repurchase programs } \\
\hline TCS Group & $\begin{array}{c}\text { Rate of delivery: } 100 \% \text { (650 th shares) } \\
\text { Start: Match 12, } 2020 \\
\text { Finish: March 31, } 2020 \\
\end{array}$ & 650 th shares & 0.37 & - \\
\hline \multirow{2}{*}{ Magnit } & $\begin{array}{c}\text { Rate of delivery: } 100 \% \text { (164.71 th shares) } \\
\text { Start: April 01, } 2019 \\
\text { Finish: April 05, } 2019 \\
\end{array}$ & $\begin{array}{c}164.71 \text { th } \\
\text { shares }\end{array}$ & 0.16 & 58 \\
\hline & $\begin{array}{c}\text { Rate of delivery: } 100 \% \text { (RUR } 22.2 \mathrm{ml}) \\
\text { Start: September 29, } 2018 \\
\text { Finish: March 01, 2019 } \\
\end{array}$ & RUR $22.2 \mathrm{ml}$ & - & 58 \\
\hline Lenta & $\begin{array}{c}\text { Rate of delivery: } 8.46 \% \text { (RUR } 980.8 \mathrm{ml} \text { ) } \\
\text { Start: October 29, } 2018 \\
\text { Finish: April 02, } 2019 \\
\end{array}$ & RUR $11.6 \mathrm{ml}$ & 0.93 & 43 \\
\hline Lukoil & $\begin{array}{c}\text { Rate of delivery: } 100 \%(\$ 3 \mathrm{ml}) \\
\text { Start: August } 30,2018 \\
\text { Finish: August } 20,2019\end{array}$ & $\$ 3 \mathrm{ml}$ & 4.96 & 5 \\
\hline Megafon & $\begin{array}{c}\text { Rate of delivery: } 100 \% \\
\text { Start: August, } 2018 \\
\text { Finish: May, } 2019\end{array}$ & $\$ 1.1 \mathrm{ml}$ & - & 61 \\
\hline
\end{tabular}

Note: Dashes indicate data not available

Source: BCS Express https://bcs-express.ru/buybacks; Expert online https://expert.ru/ratings/renkingustojchivogo-razvitiya---100/

By comparing the information about the companies' buyback programs with Sustainable Development Ranking-100, it becomes evident that half of the 20 companies that are currently running share buyback programs are included in Sustainable Development Ranking-100. This suggests that share repurchases are subject to quite 'strong' companies.

The companies actively use buybacks to maintain their share prices, as evidenced by the contribution of share repurchases to stock performance. Table 2 illustrates this trend by providing data about four Russian gas and oil producers: Rosneft, Lukoil, Gaspromneft and Tatneft.

Table 2. Buybacks and stock performance of Rosneft, Lukoil, Gaspromneft and Tatneft (MarchOctober, 2020)

\begin{tabular}{|l|c|c|c|c|c|}
\hline \multirow{3}{*}{ Month } & $\begin{array}{c}\text { Ratio of } \\
\text { buybacks to } \\
\text { Rosneft stock } \\
\text { trading } \\
\text { volume of (\%) }\end{array}$ & Rosneft & Lukoil & Gaspromnef & Tatneft \\
\cline { 3 - 5 } & & & &
\end{tabular}


Table 2. Continued

\begin{tabular}{|c|c|c|c|c|c|}
\hline March & 5.1 & 14.7 & 12.9 & 14.9 & 9.7 \\
\hline April & 4.0 & 6.8 & 2.4 & 10.0 & -0.5 \\
\hline May & 1.6 & 12.1 & 8.6 & -0.7 & -3.3 \\
\hline June & 1.0 & -3.8 & 1.3 & -0.1 & 4.6 \\
\hline July & 3.4 & -1.4 & -4.2 & -3.5 & -0.3 \\
\hline August & 2.1 & 4.6 & -1.9 & -0.9 & -1.2 \\
\hline September & 12.4 & 2.6 & -10.4 & -7.3 & -15.4 \\
\hline October & 7.8 & 1.5 & 0.1 & -2.2 & 1.0 \\
\hline
\end{tabular}

Source: [24]

As can be seen from Table 2, there is a noticeable difference between the performance of Rosneft shares and the growth of share portfolio of the company's competitors. For example, for four months (May, August, September and Octover) Rosneft shares were outperforming quotations of Lukoil, Gazpromneft, and Tatneft. For three months Rosneft was the second. These results are related to the volume of repurchases in the average daily turnover. Some Russian companies (e.g., Lukoil) in addition to share repurchase also used interim dividends as components of manager remuneration schemes [26]. In order to simplify the buyback procedure, the Central Bank of Russia introduced amendments to corporate legislation [27].

In contrast to foreign practice, the Russian literature lacks discussions about the relationship between share repurchases and manager remuneration, and bailouts. When the American aviation giants Delta and United asked for government rescue, senior executives had to suspend stock buybacks until federal loans that the companies were planning to receive as a form of bailout matured. Boeing was expected to receive government bailout support topped the scale $\$ 60$ billion and also had to suspended buybacks and dividend payments. In 2020 the US Federal Reserve System (FRS) has set limits on dividend payments and share repurchases for 33 US banks with assets valued $\$ 100$ billion. The European Banking Federation also called for the cancellation of dividend payouts and share buybacks for the entire period of 2020. In Europe, dividend and buyback programs are considered 'socially unacceptable' due to the pandemic impact. At the beginning of this year, the Central Bank of Russia also instructed banks to postpone buybacks and dividend payments till autumn.

\section{Benefits and risks of share repurchases for shareholders and stakeholders}

What are the benefits and risks that share repurchases can bring to shareholders and different stakeholders? Generally speaking, there are four main motives underlying the decision to buy back shares: (1) to maintain the value of shares at competitive level; (2) to reduce the number of shares in circulation (redemption of shares); (3) top management remuneration schemes; and (4) tax optimization. However, if in future shares are sold in a large investor's favour, this may pose risks in terms of redistribution of shareholder control. Another important issue is the objectivity of the repurchasing price when top management have share options. The benefits and shortcomings of buybacks are presented in Table 3. 
Table 3. Benefits and shortcomings of share buybacks

\begin{tabular}{|c|c|}
\hline Benefits & Shortcomings \\
\hline $\begin{array}{l}\text { Buybacks represent a positive net present } \\
\text { value opportunity for a firm's } \\
\text { shareholders if shares are being } \\
\text { repurchased during periods when they } \\
\text { are undervalued. When the market } \\
\text { situation improves, shares will be sold at } \\
\text { higher prices. } \\
\text { Buyback are used to increase earnings per } \\
\text { share. Corporations use buybacks as an } \\
\text { alternative to dividend payments to } \\
\text { increase shareholder wealth. } \\
\text { Buyback are used as component of top } \\
\text { management remuneration } \\
\text { employee incentive schemes. } \\
\text { Buybacks are a more tax-efficient way to } \\
\text { return capital to shareholders. Share } \\
\text { repurchases are taxed at a lower rate and } \\
\text { have a tax advantage over dividend } \\
\text { payments. } \\
\text { Buybacks are used for corporate tax } \\
\text { optimization. }\end{array}$ & $\begin{array}{l}\text { Buybacks decrease investment opportunities } \\
\text { since they are funded by cash. } \\
\text { Buybacks create an artificial demand for a } \\
\text { firm's shares. Although the firm's } \\
\text { market value might grow, it does not } \\
\text { lead to improved efficiency. This } \\
\text { situation is misleading for investors, } \\
\text { since stock prices may decline in future. } \\
\text { Repurchasing shares is found to transfer } \\
\text { wealth from shareholders to top } \\
\text { management. This is regulated by } \\
\text { corporate compliance and share } \\
\text { repurchases are required to be publicly } \\
\text { announced. } \\
\text { Funding buybacks is considered unethical, } \\
\text { since it enriches senior managers and } \\
\text { shareholders if used as an incentive, } \\
\text { while these financial resources could } \\
\text { target better working conditions. } \\
\text { Holding company shares can be repurchased } \\
\text { by subsidiaries when shares are not } \\
\text { redeemed. If the holding company and } \\
\text { subsidiary are located in different legal } \\
\text { entities, tax authorities may consider } \\
\text { buybacks as a scheme for avoiding taxes } \\
\text { and charge additional taxes. } \\
\text { Buybacks are believed to dilute shareholder } \\
\text { value. }\end{array}$ \\
\hline
\end{tabular}

Source: https://cyberleninka.ru/article/n/corporate-stock-buyback-pro-et-contra; [1]; [28]

However, due to a relatively weak status of Russian stakeholders, public opinion and expert community do not give much consideration to negative impacts of share repurchases on stakeholders' interests. In this regard, future research may be aimed at assessing the impact of share buybacks on risks and benefits for financial and non-financial stakeholders; studying their impact on corporate governance, and determining the impact of buybacks on long-term sustainability.

\section{Conclusions}

Companies are increasingly using share repurchases to maintain the value of their shares. In all the above discussed cases buybacks were used to increase the firm's capitalization and to boost executive incentives. In times of continuing market volatility, companies have achieved an increase in share prices. There are different types of share repurchases [2], but the general observation is that firms engaged in share repurchase programs experience a better market position [24]. Nevertheless, share repurchases are considered as an ambiguous tool for changing the value of shares. Currently the Russian shareholders' interests prevail. However, the COVID-19 is posing new serious risks of further share value reduction. The question how the risks associated with buybacks will be dealt with is still awaiting the answer.

The overall conclusion can be made that Russian researchers relate share repurchases to only shareholders' interests rather than all stakeholders' benefits. This can be explained by 
the lack of influential non-financial stakeholders who have strong ability to make important financial decisions.

\section{References}

1. J. Kennon, Cash Dividends, Share Repurchases, Which is Better for Your Portfolio? The Balance (2020)

2. N.Wessona, B.W. Bruwerb, W.D. Hammana, South African Journal of Business Management, 46(3) (2015)

3. T. Evgeniou, E.J. de Fortuny, N. Nassuphis, T. Vermaelen, Journal of Corporate Finance, 49 (2018)

4. F.E. Fama, K.R. French, Journal of Financial Economics, 116(1) (2015)

5. F.R. Stambaugh, Y. Yuan, The Review of Financial Studies, 30(4), 1270 (2017)

6. E. York, The Economics of Stock Buybacks (2018)

7. H. Dawid, Ph. Harting, S. van der Hoog, Manager Remuneration, Share Buybacks and Firm Performance (2018)

8. W. Lazonick, Buybacks: from basics to politics (2015).

9. W. Lazonick, M.E. Sakinç, M. Hopkins, Harvard Business Review (2020)

10. J.W. Gruber, S. Kamin, Corporate Buybacks and Capital Investment: An International Perspective (2017)

11. J. Mackey, R. Sisodia, Conscious Capitalism. Liberating the Heroic Spirit of Business (2015)

12. I.N. Tkachenko, Economy of Region, 14, 3 (2018)

13. J. Sheth, Industrial Marketing Management, 88 (2020)

14. E. Lonergan, M. Blyth, Beyond bailouts (2020)

15. W. Zhang, Stock buybacks: some old norm should remain new, Law and COVID-19 (2020)

16. C. Rees, D. Offenbach, Towards Democratic and Sustainable Business: Possibilities for Corporate Governance Reform (2020)

17. L. Palladino, International Review of Applied Economics, 34(2), 152 (2020)

18. B.S. Bataeva, I.N. Tkachenko, II International Scientific Conference GCPMED (2019)

19. I. Tkachenko, I. Pervukhina, Stakeholder Value Assessment: Attaining CompanyStakeholder Relationship Synergy, Corporate Governance in Central Europe and Russia

20. A.S. Firsanov, D.M. Petrova, A.A.Tsaytsev, Buybacks: international and Russian experience, Conference Proceeding (2019)

21. A.V. Kravtsov, V.M. Molokanov, Achievements and prospects for the development of youth science (2019)

22. V.A. Grebennikova, E.I. Polyakov, Sustainable Development Economy, 1(41), 190 (2020)

23. V. Gaidaev, Issuers and top managers have come to the sale, Kommersant (2020)

24. D. Puchkaryov, What buyback is the strongest in the Russian market, BCS Express (2020)

25. AFK Sistema extends the buyback program, BCS Express (2020)

26. Lukoil has decided on interim dividends, BCS Express (2020) 
27. E. Vavina. "Rosneft" will facilitate the redemption of shares due to falling oil prices. Vedomosti (2020)

28. G. Guthrie, The Dark Side of Share Buybacks, SSRN (2020) 